\title{
PENGARUH JUMLAH ANGGOTA, SIMPANAN, PINJAMAN DAN MODAL KERJA TERHADAP SHU PADA KOPERASI KPRI MITRA KABUPATEN MAJALENGKA
}

Oleh :

Yelsha Dwi Pasca,

Program Studi Manajemen, Sekolah Tinggi Ilmu Ekonomi Stmy

Email : yelshadwipasca@gmail.com

\section{Article Info}

Article History:

Received 30 August - 2021

Accepted 16 Sept - 2021

Available Online 25 Sept 2021

\section{Keyword :}

Total of members, Deposits, Loans, Working Capital, SHU

\begin{abstract}
The purpose of this study was to determine the effect of the number of members, total deposits, total loans and working capital on the acquisition of Business Profits (SHU) in the KPRI Mitra Koperasi of SMA Negeri 1 Maja, Majalengka. The data source uses secondary data, namely financial statement data. The financial report data used in this thesis is data for the last 6 years from 2015 to 2020 at the KPRI Mitra SMA Negeri 1 Maja, Majalengka. The sampling method used in this study, which is more specifically the type or method of non-probability sampling used in this study, is purposive sampling. Based on the results of research that has been done that the correlation coefficient simultaneously (together) between the total of members, deposits, loans, working capital to the remaining operating results, that the $R$ Square is 0.550. This value is the result of the square of the correlation coefficient. The value of Rsquare $x$ $100 \%$ is called the coefficient of determination. In this case it means that $55 \%$ of the influence of the total of members, total deposits, total of loans, working capital on the remaining operating results. For the rest, $(100 \%-55 \%=45 \%)$ caused by other factors that were not studied. The result of interpretation of the coefficient of determination is 55\%. Included in the strong or high influence. Based on the results of the F / ANOVA test, Fcount $=4.769$ with a significance level of 0.000. As for the value of Ftable $=0.225$ at a significance level of 0.05. So that Fcount $>$ Ftable $(4.769>0.225)$ with a significance value of $0.000<$ 0.05 which indicates a significant regression model. So the conclusion is Fcount > Ftable, then $\mathrm{HO}$ is rejected, meaning the total of members, total deposits, total loan, working capital simultaneously affect the SHU at the Koperasi KPRI Mitra of SMA Negeri 1 Maja, Majalengka.
\end{abstract}

\section{PENDAHULUAN}

Koperasi merupakan salah satu kekuatan ekonomi yang tumbuh di kalangan masyarakat sebagai pendorong tumbuhnya perekonomian nasional sekaligus sebagai soko guru dalam perekonomian di Negara Indonesia. Menurut
UU no. 25 Tahun 1992 tentang perkoperasian Bab I Pasal 1, "Koperasi adalah badan usaha yang beranggotakan orang seorang atau badan hukum koperasi dengan melandaskan kegiatannya berdasarkan prinsip koperasi sebagi gerakan ekonomi rakyat yang 
berdasarkan atas azas kekeluargaan."

Koperasi KPRI Mitra SMA Negeri 1 Maja merupakan salah satu koperasi pegawai republik indonesia (KPRI) yang ada di Kabupaten Majalengka. Seperti koperasi pada umumnya, koperasi ini juga bertujuan untuk meningkatkan kesejahteraan anggotanya melalui kegiatan simpan pinjam. Untuk dapat menjalankan dan meningkatkan kegiatan operasionalnya satu-satunya tersebut, Koperasi KPRI Mitra SMA Negeri 1 Maja terus berusaha mengoptimalkan modal yang ada dari anggota berlandaskan prinsip koperasi dengan perangkat organisasi yang terdiri dari : Rapat Anggota, Pengurus, Pengawas.

Sekalipun koperasi tidak mengejar keuntungan, koperasi diharapkan untuk memperoleh keuntungan yang layak, sehingga koperasi mampu memperkuat dan mengembangkan kemampuan usahanya. Koperasi tidak menggunakan istilah keuntungan untuk menunjukkan selisih antara penghasilan yang diterima selama periode tertentu dengan pengorbanan yang dikeluarkan untuk memperoleh penghasilan. Selisih tersebut dikenal sebagai Sisa Hasil Usaha (SHU) atas dasar besarnya jasa anggota yang diberikan kepada koperasi. Menurut Taman (2012:5), "Dalam mencapai tujuan tersebut koperasi seringkali menghadapi kendala antara lain: jumlah anggota, jumlah simpanan, jumlah pinjaman dan modal kerja." Mitra

Tabel.1 Jumlah Anggota Koperasi KPRI

\begin{tabular}{|c|c|}
\hline Tahun & Jumlah Anggota \\
\hline 2015 & 94 \\
\hline 2016 & 92 \\
\hline 2017 & 84 \\
\hline 2018 & 83 \\
\hline 2019 & 84 \\
\hline 2020 & 78 \\
\hline
\end{tabular}

Sumber: Data Sekunder, 2021

Berdasarkan tabel 1.1 terdapat masalah yang muncul dari segi jumlah anggota, pertumbuhan jumlah anggota dalam koperasi berjalan sangat lambat malah semakin menurun jumlah anggotanya. Hal ini disebabkan karena kurangnya partisipasi anggota terhadap informasi dalam koperasi, sehingga koperasi masih sangat kesulitan untuk berkembang.

Tabel. 1.2 Jumlah Simpanan Koperasi
KPRI Mitra

\begin{tabular}{|c|c|}
\hline Tahun & $\begin{array}{c}\text { Jumlah Simpanan } \\
(\mathrm{Rp})\end{array}$ \\
\hline 2015 & 430.612 .628 \\
\hline 2016 & 424.685 .027 \\
\hline 2017 & 392.977 .500 \\
\hline 2018 & 432.701 .524 \\
\hline 2019 & 454.678 .524 \\
\hline 2020 & 464.655 .216 \\
\hline
\end{tabular}

Sumber: Data Sekunder, 2021

Berdasarkan tabel 1.2 terdapat masalah yang muncul dari segi simpanan. Dari tahun 2015 ke tahun 2017 mengalami penurunan, kemudian dari tahun 2017 ke tahun 2020 mengalami peningkatan. Terbatasnya modal yang ada dalam koperasi menyebabkan sulitnya mengembangkan unit-unit usaha yang diharapkan mampu meningkatkan kesejahteraan anggota.

Tabel. 2 Jumlah Pinjaman Koperasi KPRI Mitra

\begin{tabular}{|c|c|}
\hline Tahun & Jumlah Pinjaman \\
\hline 2015 & 576.703 .800 \\
\hline 2016 & 537.678 .250 \\
\hline 2017 & 431.842 .087 \\
\hline 2018 & 409.858 .700 \\
\hline 2019 & 456.908 .337 \\
\hline 2020 & 343.186 .446 \\
\hline
\end{tabular}

Sumber: Data Sekunder, 2021

Berdasarkan tabel 1.3 terdapat permasalahan dari pemberian jumlah pinjaman. Dari tahun 2015 sampai tahun 2018 mengalami penurunan dalam jumlah pinjaman. Sedangkan dari tahun 2018 sampai tahun 2019 terjadi peningkatan jumlah pinjaman. Kemudian dari tahun 2019 ke tahun 2020 mengalami penurunan jumlah pinjaman. Pemberian pinjaman terbatas karena modal yang juga terbatas. Selain itu, pemanfaatan modal yang kurang baik juga dapat menghambat peningkatan SHU koperasi.

Tabel. 3 Modal Kerja Koperasi KPRI Mitra

\begin{tabular}{|c|c|}
\hline Tahun & Modal Kerja \\
\hline 2015 & 381.810 .312 \\
\hline 2016 & 398.694 .012 \\
\hline 2017 & 386.095 .162 \\
\hline 2018 & 407.789 .329 \\
\hline 2019 & 440.112 .524 \\
\hline 2020 & 452.787 .011 \\
\hline
\end{tabular}

Sumber: Data Sekunder, 2021

Berdasarkan tabel 1.4 terdapat permasalahan dari segi modal kerja yang fluktuatif. Pada tahun 2015 sampai tahun 2016 mengalami peningkatan modal kerja. Dari 
tahun 2016 ke tahun 2017 mengalami penurunan. Sedangkan dari tahun 2017 sampai tahun 2020 mengalami peningkatan dalam modal kerja. Modal kerja merupakan modal yang selalu berputar dalam koperasi dan setiap perputaran akan menghasilkan pendapatan bagi koperasi. Apabila modal kerja tidak efisien, maka akan berdampak pada pendapatan yang akan diterima koperasi. Keterlibatan anggota dalam kegiatan-kegiatan koperasi dan komitmen para anggota terhadap koperasi akan sangat berpengaruh terhadap kelangsungan hidup koperasi. Anggota yang memiliki jasa besar dalam usaha koperasi akan meningkatkan SHU pada koperasi.

\section{KAJIAN PUSTAKA DAN PEGEMBANGAN HIPOTESIS Manajemen Keuangan}

Manajemen keuangan tidak hanya berkutat pada penggunaan serta pengalokasian dana secara efisien, seiring dengan berjalannya waktu manajemen keuangan juga mencakup kegiatan-kegiatan lainnya, seperti cara mendapatkan dana, penggunaan dana dan pengelolaan aset (aktiva). Beberapa pengertian manajemen keuangan didefinisikan sebagai berikut : Menurut Van Horne yang diterjemahkan oleh Heru Sutojo (2007 : 2), manajemen keuangan adalah : "Segala aktivitas berhubungan dengan perolehan, pendanaan, dan pengelolaan aktiva dengan beberapa tujuan menyeluruh. Oleh karena itu fungsi pembuatan keputusan dari manajemen keuangan dapat dibagi menjadi tiga area utama keputusan sehubungan investasi, pendanaan dan manajemen aktiva." Sedangkan menurut Bambang Riyanto (2005 : 4), manajemen keuangan adalah : "Keseluruhan aktiva yang bersangkutan dengan usaha untuk mendapatkan dana dan menggunakan atau mengalokasikan dana tersebut." Secara umum dapat ditarik kesimpulan manajemen keuangan adalah kegiatan-kegiatan perusahaan ataupun organisasi yang berkaitan dengan cara untuk memperoleh pendanaan modal kerja, menggunakan dana tersebut dengan efektif, serta mengelola aset-aset yang dimiliki untuk mencapai tujuan perusahaan tersebut.

\section{Koperasi}

Undang-Undang Dasar

khususnya pasal 33 ayat (1) menyatakan bahwa perekonomian Indonesia disusun sebagai usaha bersama berdasarkan atas asas kekeluargaan. Koperasi mempunyai peranan penting dalam membantu masyarakat golongan menengah kebawah untuk dapat meningkatkan kesejahteraan para anggotanya. Menurut Undang-Undang perekonomian No. 25 Tahun 1992 pengertian koperasi yaitu : "Koperasi merupakan badan yang beranggotakan orang seorang atau badan hukum koperasi yang melandaskan kegiatannya berdasarkan prinsip koperasi sekaligus sebagai gerakan ekonomi rakyat yang berdasar atas asas kekeluargaan." Meskipun koperasi bukan merupakan bentuk kumpulan modal, namun sebagai suatu badan usaha maka didalam menjalankan usahanya koperasi memerlukan modal pula. Tetapi, pengaruh modal dan penggunaannya dalam kkoperasi tidak boleh mengaburkan dan mengurangi makna koperasi, yang lebih menekannkan kepentingan kemanusiaan. Koperasi sebagai badan usaha memerlukan struktur modal yang digunakan dalam membiayai operasional usahanya untuk kesejahteraan para anggotanya.

\section{Modal}

Modal dalam arti sempit adalah sejumlah dana atau sejumlah nilai uang yang dipergunakan dalam membelanjai semua keperluan usaha. Sedangkan dalam arti luas modal adalah semua peralatan yang berupa uang atau barang yang diperlukan untuk menjalankan usaha lebih lanjut. Menurut Prof. Meij dalam bukunya Bambang Riyanto (2000 :18) "pengertian modal adalah kolektivitas dari barang-barang modal yang terdapat dalam neraca sebelah debet, sedangkan yang dimaksud dengan barang-barang modal ialah semua barang yang ada dalam rumah tangga perusahaan dalam fungsi produktifnya untuk membentuk pendapatan." Dari rumusan modal diatas dapat kita simpulkan bahwa modal merupakan semua kekayaan baik berupa uang, harta tetap maupun tidak tetap yang dapat dinilai dengan uang serta dapat digunakan untuk menjalankan kegiatan usaha. Bagi organisasi koperasi pengertian modal adalah seperti pada pasal 41 ayat $1 \mathrm{UU}$ No.25 Th 1992 tentang perkoperasian, bahwa 
modal koperasi terdiri dari modal sendiri dan modal pinjaman. Pengertian modal koperasi menurut pasal tersebut adalah pengertian modal ditinjau dari kedudukan atau statusnya, modal sendiri merupakan modal yang menanggung resiko kerugian sedangkan modal pinjaman juga merupakan modal yang ikut menanggung resiko kerugian. Agar permodalan koperasi kuat, maka modal sendiri komposisinya harus lebih besar dari modal pinjaman. Keberhasilan koperasi didalam melaksanakan perannya sebagai badan usaha sangat tergantung pada kemampuan koperasi menghimpun dan menanamkan modalnya dengan cara pemupukan berbagai sumber keuntungan dan banyaknya jumlah anggota. Modal dari anggota bersumber dari simpanan pokok, simpanan wajib, dana cadangan dan hibah. Hal ini tercermin bahwa koperasi sebagai badan usaha yang ingin mendorong diri sendiri dengan kekuatan sendiri.

\section{SHU}

Sisa Hasil Usaha (SHU) adalah pendapatan koperasi yang diperoleh dalam waktu satu tahun buku dikurangi dengan biaya, penyusutan, dan kewajiban lainnya termasuk pajak dalam tahun buku yang bersangkutan (UU No.25 Tahun 1992 Pasal 1 \& 2). Usaha koperasi yang utama diarahkan pada bidang usaha yang berkaitan langsung dengan kepentingan anggota baik untuk menunjang usaha maupun kesejahteraan anggotanya. Berkaitan dengan hal tersebut, maka pengelolaan usaha koperasi harus dilakukan dengan produktif, efektif, dan efisien. Dalam arti koperasi harus mempunyai kemampuan mewujudkan pelayanan usaha yang dapat meningkatkan nilai tambah dan manfaat yang sebesar-besarnya terhadap anggota dan masyarakat pada umumnya dengan tetap mempertimbangkan untuk memperoleh SHU yang wajar. Sisa Hasil Usaha adalah pendapatan yang diperoleh dalam satu tahun dikurangi penyusutan dan beban-beban dari tahun buku yang bersangkutan (Soemarso, 2005:208). Pada hakikatnya sisa hasil usaha koperasi sama dengan laba untuk perusahaan yang lain. Sisa hasil usaha setelah dikurangi dana cadangan, dibagikan kepada anggota sebanding dengan jasa usaha yang dilakukan oleh masing-masing anggota dengan koperasi, serta digunakan untuk keperluan pendidikan perkoperasian dan keperluan lain koperasi, sesuai dengan rapat anggota (Soemarso, 2005:208). Di dalam AD/ART koperasi telah ditentukan pembagian SHU sebagai berikut: Cadangan koperasi $40 \%$, jasa anggota $40 \%$, dana pengurus $5 \%$, dana karyawan $5 \%$, dana pendidikan 5\%, dana sosial 5\%, dana pembangunan lingkungan $5 \%$. Tidak semua komponen di atas harus diadopsi dalam membagi SHU-nya. Hal ini tergantung dari keputusan anggota yang ditetapkan dalam rapat anggota. Menurut Kartasapoetra (2003:23) SHU dibagikan kepada para anggota dilakukan bukan berdasarkan modal yang dimiliki seseorang dalam koperasi, melainkan berdasar perimbangan jasa/usaha serta kegiatankegiatan para anggota dalam mencapai keberhasilan usaha koperasi.

\section{Jumlah Anggota}

Koperasi dapat berkembang apabila badan usaha koperasi memiliki kesadaran anggota untuk berkoperasi yang tinggi. Tanpa adanya anggota, koperasi akan sulit berkembang dalam kegiatan usaha. Hal tersebut sesuai dengan pendapat yang dikemukakan oleh Ropke (2000: 45): "Tanpa partisipasi anggota, kemungkinan atas rendahnya atau menurunnya efisiensi dan efektivitas anggota dalam rangka mencapai kinerja koperasi akan lebih besar." Menurut Baswir (2012) yang dikutip oleh Bayu, dkk (2014), anggota koperasi adalah individu-individu yang menjadi bagian dari koperasi tersebut sesuai dengan persyaratan yang telah ditentukan. Sebagai anggota koperasi wajib membayar sejumlah uang untuk simpanan pokok dan simpanan wajib koperasi. Menurut UndangUndang No. 25 tahun 1992 pasal 17 ayat (1) menyatakan bahwa anggota koperasi merupakan pemilik dan sekaligus pengguna jasa koperasi. Disini dapat disimpulkan bahwa anggota dapat memiliki dan memanfaatkan ekonomi yang disediakan dan sesuai dengan modal yang disetor anggota ke koperasi. Sehingga koperasi dapat dikatakan berkembang tidaknya ditentukan dari para anggotanya. 


\section{Pinjaman}

Menurut Winarno dan Ismaya (2003: 289), yang dikutip oleh Thamrin (2013), pinjaman adalah pemberian sejumlah uang dari suatu pihak (lembaga keuangan, seseorang atau perusahaan) kepada pihak lain (seseorang atau perusahaan) yang mewajibkan pinjamannya untuk melunasi dalam jangka waktu tertentu dengan jumlah bunga yang disepakati bersama. Menurut Sitio dan Halomoan (2001: 85), pinjaman yang ada dalam koperasi bersumber dari modal pinjaman yang terdiri dari: 1.Anggota. Anggota yaitu pinjaman dari anggota ataupun calon anggota koperasi yang bersangkutan. 2.Koperasi lainnya. Koperasi lainnya yaitu pinjaman dari koperasi lainnya dan/atau anggotanya yang didasari dengan perjanjian kerja sama antar koperasi. 3.Bank dan lembaga keuangan lainnya. Bank dan lembaga keuangan lainnya yaitu pinjaman dari bank dan lembaga keuangan lainnya yang dilakukan berdasarkan ketentuan peraturan perundang-undangan yang berlaku. 4.Penerbitan obligasi dan surat hutang lainnya. Penerbitan obligasi dan surat hutang lainnya yaitu dana yang diperoleh dari penerbitan obligasi dan surat hutang lainnya berdasarkan ketentuan perundang-undangan yang berlaku. 5.Sumber lain yang sah. Sumber lain yang sah yaitu pinjaman yang diperoleh dari bukan anggota yang dilakukan tanpa melalui penawaran secara umum.

\section{Simpanan}

Menurut IAI (2009: 27-7), yang dikutip oleh Thamrin (2013), simpanan anggota yang berkarakteristik sebagai ekuitas adalah sejumlah tertentu dalam nilai uang yang diserahkan oleh anggota koperasi atas kehendak sendiri sebagai simpanan dan dapat diambil sewaktu-waktu sesuai perjanjian. Simpanan ini tidak menanggung resiko kerugian dan sifatnya sementara karenanya diakui sebagai kewajiban. Menurut Sitio dan Halomoan (2001: 84), jumlah simpanan yang ada dalam koperasi bersumber dari modal sendiri yang terdiri dari: 1.Simpanan pokok. Simpanan pokok yaitu sejumlah uang yang sama banyaknya, yang wajib dibayarkan oleh masing-masing anggota kepada koperasi pada saat masuk menjadi anggota. 2.Simpanan wajib. Simpanan wajib yaitu sejumlah simpanan tertentu yang tidak harus sama banyaknya, yang wajib dibayarkan oleh anggota kepada koperasi pada periode tertentu. 3.Dana cadangan. Dana cadangan yaitu sejumlah dana yang diperoleh dari penyisihan Sisa Hasil Usaha (SHU) dan dicadangkan untuk menutupi kerugian koperasi bila diperlukan.4. Donasi. Donasi yaitu sejumlah uang atau barang dengan nilai tertentu yang disumbangkan oleh pihak ketiga, tanpa ada suatu ikatan atau kewajiban untuk mengendalikannya

\section{Kerangka Pemikiran}

Koperasi dalam menjalankan usaha membutuhkan kontribusi modal dari anggota untuk membiayai kegiatan usaha. Berdasarkan tujuan koperasi yaitu mempromosikan anggota maka yang diperjuangkan adalah agar anggota dapat meraih laba yang sebesar besarnya. Sebagai badan usaha yang bergerak di bidang kegiatan ekonomi, koperasi sangat memerlukan modal sebagai pembiayaan dari usahanya tersebut. Besar kecilnya nilai modal yang ada pada koperasi menentukan pula besar kecilnya lapangan usaha yang dijalankan koperasi tersebut. Sehingga dengan demikian faktor modal dalam usaha koperasi merupakan salah satu alat yang ikut menentukan maju mundurnya koperasi. Tanpa adanya modal ini, sesuatu yang bersifat ekonomis tidak akan berjalan sebagaimana mestinya. Menurut Tohar (2000:30), modal kerja koperasi adalah jumlah uang yang tertanam dalam aktiva lancar koperasi. Masalah modal kerja sangat erat hubungannya dengan dengan operasi badan usaha sehari-hari. Tersedianya modal kerja yang cukup sangat penting bagi badan usaha, karena badan usaha tersebut dapat memenuhi kebutuhannya dalam pembiayaan operasi sehari-hari dengan cukup pula. Modal kerja yang berlebihan menunjukkan adanya dana yang tidak produktif dan sebenarnya merupakan kerugiaan bagi badan usaha, karena kesempatan untuk memperoleh keuntungan yang lebih besar disia-siakan. Hal ini tidak sesuai dengan penelitian Taman (2012), bahwa semakin banyak modal kerja maka koperasi tersebut akan dapat melakukan berbagai usaha untuk dapat meningkatkan SHU. Sementara 
menurut Muljono (2012), bahwa semakin besar modal kerja maka akan lebih memungkinkan koperasi untuk mencapai SHU yang diharapkan. Pengelolaan simpanan pokok dan simpanan wajib sangat berpengaruh terhadap besarnya perolehan SHU yang dihasilkan oleh Koperasi KPRI Mitra SMA Negeri 1 Maja Kabupaten Majalengka. Apabila dalam menjalankan usahanya koperasi menggunakan modal sendiri dan modal pinjaman dengan baik maka keuntungan yang diperoleh cenderung lebih tinggi, sehingga SHU yang diperoleh diharapkan juga semakin tinggi.

Secara sistematis untuk memudahkan alur pembahasan dari penelitian ini disusun paradigma penelitian seperti tampak dalam gambar sebagai berikut:

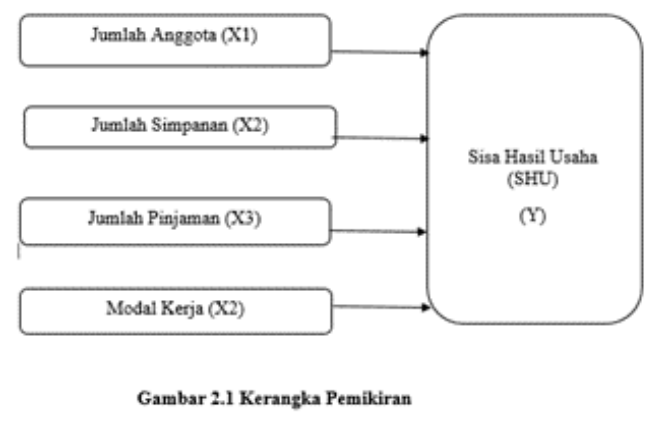

\section{Hipotesis Penelitian}

Berdasarkan pada kerangka pemikiran di atas, hipotesis penelitian yang diajukan adalah sebagai berikut:

1.Terdapat pengaruh jumlah anggota terhadap sisa hasil usaha pada koperasi KPRI Mitra SMA Negeri 1 Maja, Kabupaten Majalengka.

2. Terdapat pengaruh jumlah simpanan terhadap sisa hasil usaha pada koperasi KPRI Mitra SMA Negeri 1 Maja, Kabupaten Majalengka.

3.Terdapat pengaruh jumlah pinjaman terhadap sisa hasil usaha pada koperasi KPRI Mitra SMA Negeri 1 Maja, Kabupaten Majalengka.

4. Terdapat pengaruh modal kerja terhadap sisa hasil usaha pada koperasi KPRI Mitra SMA Negeri 1 Maja, Kabupaten Majalengka.

5.Terdapat pengaruh jumlah anggota, jumlah simpanan, jumlah pinjaman dan modal kerja terhadap sisa hasil usaha pada koperasi KPRI Mitra SMA Negeri 1 Maja, Kabupaten Majalengka.

\section{METODE PENELITIAN}

Dalam melakukan penelitian ini, metode yang di pakai adalah metode verifikatif dengan pendekatan kuantitatif yaitu dengan menggunakan teknik analisis regresi linear berganda. Analisis regresi linier berganda dilakukan untuk mengetahui adanya hubungan/pengaruh antara variabel dependen dengan variabel independent. Untuk mempermudah peneliti dalam menganalisis data serta agar hasil yang diperoleh lebih akurat dan efisien, maka perhitungannya menggunakan bantuan program komputer SPSS (Statistical Product and Service Solutions).

\section{Populasi dan Sampel}

Populasi penelitian adalah keseluruhan subyek yang akan diteliti. Populasi yang dimaksud dalam penelitian ini adalah keseluruhan laporan keuangan (hasil RAT) Koperasi KPRI Mitra SMA Negeri 1 Maja Kabupaten Majalengka dari awal berdiri dari tahun 1999 sampai dengan Tahun 2021 atau selama kurun waktu 22 tahun. Teknik penarikan sampel yang digunakan dalam penelitian ini adalah teknik sampling secara nonprobabilitas, yaitu teknik pengambilan sampel yang ditemukan atau ditentukan sendiri oleh peneliti atau menurut pertimbangan pakar. Secara lebih spesifiknya jenis atau cara penarikan sampel secara nonprobabilitas yang digunakan dalam penelitian adalah Purposive Sampling. Metode ini merupakan sebuah cara untuk mendapatkan sampel dengan memilih sampel di antara populasi sesuai dengan yang dikehendaki oleh peneliti dan dianggap mewakili. Dalam hal ini peneliti mengambil sampel sebanyak $15 \%$ dari populasi yaitu sampel berupa data laporan keuangan (hasil RAT) Koperasi Koperasi KPRI Mitra SMA Negeri 1 Maja kabupaten Majalengka dari tahun 2015 sampai dengan tahun 2020 (kurun waktu enam tahun terakhir).

\section{HASIL DAN PEMBAHASAN}

Analisis regresi sederhana didasarkan pada hubungan fungsional ataupun kausal satu variabel independen dengan satu variabel dependen. Kemudian analisis regresi ganda digunakan oleh peneliti, bila peneliti bermaksud meramalkan bagaimana keadaan (naik turunnya) variabel dependen (kriterium), bila dua atau lebih variabel independen sebagai faktor predikator dimanipulasi (dinaik turunkan nilainya). Berikut hasil analisis regresi: 
Tabel 4

Hasil Uji Regresi

Jumlah Anggota, Simpanan, Pinjaman, Modal

Kerja, Sisa Hasil Usaha

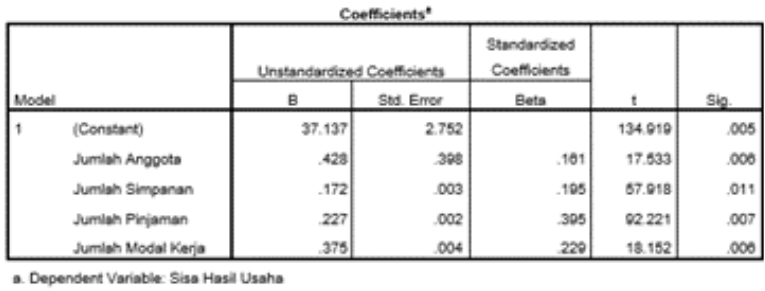

Berdasarkan tabel tersebut dapat dilihat bahwa nilai thitung adalah $134.919 ; 17.533$; $57.918 ; 92.221 ; 18.152$. Sedangkan nilai ttabel $=12.706(\mathrm{df}=\mathrm{n}-\mathrm{k} \quad \mathrm{n}=$ banyak sampel $\mathrm{k}=\mathrm{jumlah}$ variabel $\mathrm{df}=\mathrm{n}-\mathrm{k}=6-5=1$ ) sehingga thitung $\geq$ ttabel. Artinya konstanta dan koefisien regresi signifikan atau secara simultan $\mathrm{X} 1, \mathrm{X} 2, \mathrm{X} 3, \mathrm{X} 4$ berpengaruh signifikan terhadap $\mathrm{Y}$ atau jumlah anngota, jumlah simpanan, jumlah pinjaman dan modal berpengaruh signifikan terhadap sisa hasil usaha secara simultan. Artinya Ha diterima dan Ho ditolak. Dengan demikian, hipotesis penelitian yang menyatakan jumlah anggota, jumlah simpanan, jumlah pinjaman, modal kerja secara simultan berpengaruh terhadap SHU pada Koperasi KPRI Mitra SMA Negeri 1 Maja Kabupaten Majalengka dapat diterima. Model persamaan yang terbentuk dari uji koefisien tersebut adalah sebagai berikut:

$$
\mathrm{Y}=37.137+0.428 \mathrm{X} 1+0.172 \mathrm{X} 2+0.227
$$
$+0.375$

Dari persamaan tersebut dapat disimpulkan beberapa hal sebagai berikut:

1. Konstanta sebesar 37.137 menunjukkan bahwa jika tidak ada jumlah anggota, jumlah simpanan, jumlah pinjaman, modal kerja maka sisa hasil usaha bernilai 37.137.

2. Koefisien regresi $0.428 ; 0.172$; $0.227 ; 0.375$ menyatakan bahwa setiap penambahan (karena tanda + ) satu skor X1, X2 X3, X4 akan memberikan peningkatan skor $0.428 ; 0.172 ; 0.227 ; 0.375$ terhadap Y. Namun sebaliknya, jika jumlah anggota, jumlah simpanan, jumlah pinjaman, modal kerja turun sebesar satu skor, maka sisa hasil usaha juga mengalami penurunan sebesar0.428 ; $0.172 ; 0.227 ; 0.375$. Jadi tanda + menyatakan arah hubungan yang searah. Artinya, kenaikan atau penurunan variabel jumlah anggota, jumlah simpanan, jumlah pinjaman, modal kerja akan mengakibatkan kenaikan atau penurunan terhadap variabel sisa hasil usaha.

Untuk mengetahui seberapa besar kontribusi variabel jumlah anggota, simpanan, pinjaman, modal kerja dan sisa hasil usaha yaitu dapat dilihat berdasarkan tabel berikut:

Tabel 5

Hasil Uji Koefisien Determinasi Jumlah Anggota, Simpanan, Pinjaman, Modal Kerja dan Sisa Hasil Usaha

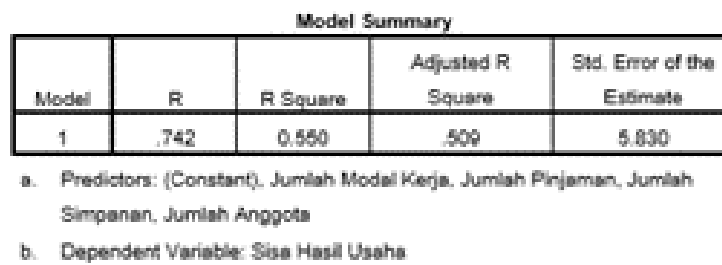

Berdasarkan tabel di atas menunjukkan bahwa koefisien korelasi secara simultan (bersama-sama) antara jumlah anggota, simpanan, pinjaman, modal kerja terhadap sisa hasil usaha, bahwa R Square adalah 0.550. Nilai tersebut adalah hasil pengkuadratan dari koefisen korelasi. Nilai Rsquare x 100\% disebut koefisien determinasi. Dalam hal ini berarti $55 \%$ pengaruh jumlah anggota, jumlah simpanan, jumlah pinjaman, modal kerja terhadap sisa hasil usaha. Untuk sisanya, $(100 \%-55 \%=45 \%)$ disebabkan oleh faktor faktor lain yang tidak diteliti. Hasil interpretasi koefisien determinasi 55\% Termasuk ke dalam pengaruh kuat atau tinggi Uji Hipotesis

Tabel 6

Hasil Uji t

Jumlah Anggota, Simpanan, Pinjaman, Modal Kerja, Sisa Hasil Usaha

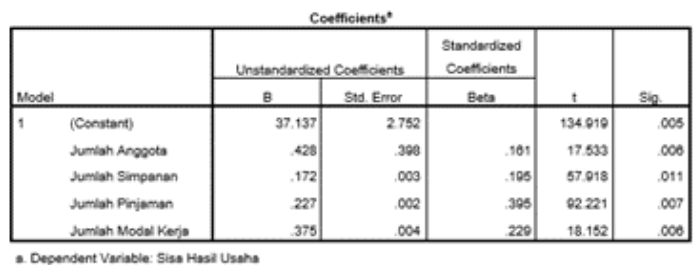

Berdasarkan tabel tersebut dapat dipaparkan sebagai berikut:

1. Nilai thitung 17.533 sedangkan nilai ttabel 
12.706. Nilai ttabel diperoleh dari $\mathrm{df}=\mathrm{n}-\mathrm{k}$ $\mathrm{n}=$ banyaknya sampel $\mathrm{k}=\mathrm{jumlah}$ variabel $\mathrm{df}=6-5=1$ sehingga tabel 12.705 . thitung $>$ ttabel dan sig <alpha penelitian $(0.006<$ 0.05) maka Ho ditolak. Artinya Terdapat pengaruh jumlah anggota terhadap SHU pada Koperasi KPRI Mitra SMA Negeri 1 Maja Kabupaten Majalengka.

2. Nilai thitung 57.918 sedangkan nilai ttabel 12.706. thitung > ttabel dan sig <alpha penelitian $(0.011<0.05)$ maka Ho ditolak. Artinya Terdapat pengaruh jumlah simpanan terhadap SHU pada Koperasi KPRI Mitra SMA Negeri 1 Maja Kabupaten Majalengka

3. Nilai thitung 92.221 sedangkan nilai ttabel 12.706. thitung > ttabel dan sig <alpha penelitian $(0.007<0.007)$ maka Ho ditolak. Artinya Terdapat pengaruh jumlah pinjaman terhadap SHU pada Koperasi KPRI Mitra SMA Negeri 1 Maja Kabupaten Majalengka

4. Nilai thitung 18.152 sedangkan nilai ttabel 12.706. thitung > ttabel dan sig <alpha penelitian $(0.011<0.006)$ maka Ho ditolak. Artinya Terdapat pengaruh modal kerja terhadap SHU pada Koperasi KPRI Mitra SMA Negeri 1 Maja Kabupaten Majalengka

Tabel 7

Hasil Uji Simultan / Uji F

Jumlah Anggota, Simpanan, Pinjaman, Modal

Kerja dan Sisa Hasil Usaha

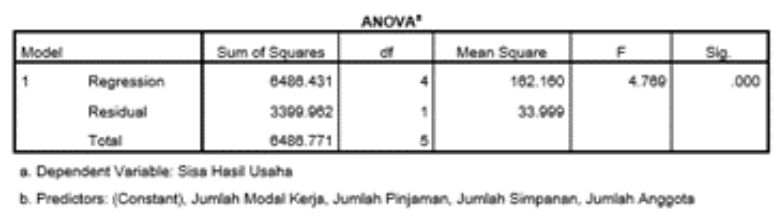

Berdasarkan hasil uji $\mathrm{F} /$ ANOVA diperoleh nilai Fhitung $=4.769$ dengan tingkat signifikansi 0.000 . Sedangkan untuk nilai Ftabel $=0.225$ pada taraf signifikansi 0,05 . Sehingga Fhitung > Ftabel $(4.769>0.225)$ dengan nilai signifikansi $0,000<0,05$ yang menunjukkan model regresi signifikan. Maka kesimpulannya Fhitung > Ftabel maka H0 ditolak berarti Jumlah anggota, jumlah simpanan, jumlah pinjaman, modal kerja secara simultan berpengaruh terhadap SHU pada Koperasi KPRI Mitra SMA Negeri 1 Maja Kabupaten Majalengka

\section{Pembahasan}

Pengaruh jumlah anggota terhadap sisa hasil usaha pada koperasi KPRI Mitra SMA Negeri 1 Maja, Kabupaten Majalengka.

Berdasarkan hasil penelitian yang telah dilakukan bahwa nilai rhitung (correlations) sebesar $0.821>$ rtabel 0.811 , maka dapat disimpulkan bahwa terdapat hubungan antara jumlah anggota dengan sisa hasil usaha . Selanjutnya nilai thitung 17.533 sedangkan nilai ttabel 12.706. Nilai ttabel diperoleh dari $\mathrm{df}=\mathrm{n}-\mathrm{k} \mathrm{n}=$ banyaknya sampel $\mathrm{k}=\mathrm{jumlah}$ variabel $\mathrm{df}=6-5=1$ sehingga tabel 12.705 . thitung $>$ ttabel dan sig <alpha penelitian $(0.006<0.05)$ maka Ho ditolak. Artinya Terdapat pengaruh jumlah anggota terhadap SHU pada Koperasi KPRI Mitra SMA Negeri 1 Maja Kabupaten Majalengka.

Hal ini sejalan dengan penelitian yang telah dilakukan oleh Dwi Rosa (2018) Hasil penelitian menunjukkan bahwa jumlah anggota dan jumlah simpanan berpengaruh positif dan signifikan dengan nila koefisien determinasi sebesar 25,8 \%.. Seperti yang telah kita ketahui bahwa jumlah anggota koperasi yang banyak akan bermanfaat sebagai tambahan modal yang didapat dari simpanan pokok dan simpanan wajib. Kekatifan anggota dalam kegiatan koperasi juga akan berpengaruh terhadap SHU.

Patisipasi anggota tidak terlepas dari status anggota koperasi sebagai suatu badan usaha yaitu sebagai pemili (owner) dan sebagai pemakai (user). Sebagai pemilik kewajiban anggota adalah melakukan investasi atau menanamkan modal di koperasinya. Sedangkan sebagai pemakai anggota harus menggunakan secara maksimal pelayanan usaha yang diselenggarakan oleh koperasi. Oleh sebab itu, status keanggotaan koperasi merupakan basis utama bagi perkembangan dan kelanjutan hidup usaha koperasi (Sitio 2001). Perkembangan dan pertumbuhan koperasi tergantung pada kualitas dan partisipasi anggotanya. Pengaruh jumlah simpanan terhadap sisa
hasil usaha pada koperasi KPRI Mitra SMA
Negeri 1 Maja, Kabupaten Majalengka.
Berdasarkan hasil penelitian yang telah 
dilakukan bahwa nilai rhitung (correlations) sebesar $0.948>$ rtabel 0.948, maka dapat disimpulkan bahwa terdapat hubungan antara jumlah simpanan dengan sisa hasil usaha. Selanjutnya Nilai thitung 57.918 sedangkan nilai ttabel 12.706. thitung $>$ ttabel dan sig $<$ alpha penelitian $(0.011<0.05)$ maka Ho ditolak. Artinya Terdapat pengaruh jumlah simpanan terhadap SHU pada Koperasi KPRI Mitra SMA Negeri 1 Maja Kabupaten Majalengka

Hal ini sejalan dengan penelitian yang telah dilakukan oleh Ferline dkk (2013) yang menyatakan bahwa jumlah anggota, simpanan anggota dan penjualan berpengaruh secara bersama-sama terhadap peningkatan Sisa Hasil Usaha (SHU) PKP-RI Provinsi Sumatera Barat. Selanjutnya Eko (2000) menyatakan bahwa Yang paling berpengaruh terhadap Sisa Hasil Usaha (SHU) adalah simpanan, dan tingkat kesehatan koperasi selama lima tahun berturutturut adalah baik dan sehat. Simpanan dalam koperasi digunakan sebagai modal sendiri dan modal pinjaman dari anggota sehingga koperasi mempunyai kewajiban untuk membayarkan jasa berupa bunga simpanan (UU No.25 Tahun 1995).

Pengaruh jumlah pinjaman terhadap sisa hasil usaha pada koperasi KPRI Mitra SMA Negeri 1 Maja, Kabupaten Majalengka.

Berdasarkan hasil penelitian yang telah dilakukan bahwa nilai rhitung (correlations) sebesar $0.924>$ rtabel 0.811 , maka dapat disimpulkan bahwa terdapat hubungan antara jumlah pinjaman dengan sisa hasil usaha. Selanjutnya Nilai thitung 92.221 sedangkan nilai ttabel 12.706. thitung > ttabel dan sig $<$ alpha penelitian $(0.007<0.007)$ maka Ho ditolak. Artinya Terdapat pengaruh jumlah pinjaman terhadap SHU pada Koperasi KPRI Mitra SMA Negeri 1 Maja Kabupaten Majalengka

Hal ini sejalan dengan penelitian yang telah dilakukan oleh Thamrin (2013) yang menyatakan bahwa terdapat pengaruh yang signifikan antara simpanan dan pinjaman anggota terhadap Sisa Hasil Usaha (SHU). Jumlah pinjaman merupakan salah satu faktor penting dalam mempengaruhi SHU karena penghasilan koperasi berasal dari bunga pinjaman. Semakin banyak jumlah pinjaman yang diberikan maka semakin banyak bunga yang diperoleh, sehingga SHU juga akan meningkat.

Pengaruh modal kerja terhadap sisa hasil usaha pada koperasi KPRI Mitra SMA Negeri 1 Maja, Kabupaten Majalengka.

Berdasarkan hasil penelitian yang telah dilakukan bahwa nilai rhitung (correlations) sebesar $0.836>$ rtabel 0.811 , maka dapat disimpulkan bahwa terdapat hubungan antara modal dengan sisa hasil usaha. Selanjutnya nilai thitung 18.152 sedangkan nilai ttabel 12.706. thitung > ttabel dan sig <alpha penelitian $(0.011<0.006)$ maka Ho ditolak. Artinya Terdapat pengaruh modal kerja terhadap SHU pada Koperasi KPRI Mitra SMA Negeri 1 Maja Kabupaten Majalengka

Hal ini sejalan dengan penelitian yang telah dilakukan oleh Vera (2013) yang menyatakan bahwa terdapat pengaruh yang positif antara modal kerja terhadap Sisa Hasil Usaha (SHU) dan menunjukkan adanya hubungan yang searah antara modal kerja dengan Sisa Hasil Usaha (SHU). Selanjutnya Bayu (2014) menyatakan bahwa modal berpengaruh positif terhadap Sisa Hasil Usaha (SHU), volume usaha berpengaruh positif terhadap Sisa hasil Usaha (SHU), jumlah anggota tidak berpengaruh terhadap Sisa Hasil Usaha. Modal, volume usaha dan jumlah anggota secara simultan berpengaruh terhadap Sisa Hasil Usaha (SHU). Ini disebabkan karena dengan semakin banyak modal kerja maka koperasi tersebut akan dapat melakukan berbagai usaha untuk dapat meningkatkan sisa hasil usaha. Jumlah modal sendiri yang dimiliki koperasi tersedia dengan baik sehingga koperasi mampu membiayai semua kegiatan operasional perusahaan.

Pengaruh jumlah anggota, jumlah simpanan, jumlah pinjaman dan modal kerja terhadap sisa hasil usaha pada koperasi KPRI Mitra SMA Negeri 1 Maja, Kabupaten Majalengka.

Berdasarkan hasil penelitian yang telah dilakukan bahwa koefisien korelasi secara simultan (bersama-sama) antara jumlah anggota, simpanan, pinjaman, modal kerja 
terhadap sisa hasil usaha, bahwa R Square adalah 0.550. Nilai tersebut adalah hasil pengkuadratan dari koefisen korelasi. Nilai Rsquare $\mathrm{x} 100 \%$ disebut koefisien determinasi. Dalam hal ini berarti $55 \%$ pengaruh jumlah anggota, jumlah simpanan, jumlah pinjaman, modal kerja terhadap sisa hasil usaha. Untuk sisanya, $(100 \%-55 \%=45 \%)$ disebabkan oleh faktor faktor lain yang tidak diteliti. Hasil interpretasi koefisien determinasi 55\% Termasuk ke dalam pengaruh kuat atau tinggi. Berdasarkan hasil uji $\mathrm{F} /$ ANOVA diperoleh nilai Fhitung $=4.769$ dengan tingkat signifikansi 0.000 . Sedangkan untuk nilai Ftabel $=0.225$ pada taraf signifikansi 0,05 . Sehingga Fhitung > Ftabel $(4.769>0.225)$ dengan nilai signifikansi $0,000<0,05$ yang menunjukkan model regresi signifikan. Maka kesimpulannya Fhitung > Ftabel maka $\mathrm{HO}$ ditolak berarti Jumlah anggota, jumlah simpanan, jumlah pinjaman, modal kerja secara simultan berpengaruh terhadap SHU pada Koperasi KPRI Mitra SMA Negeri 1 Maja Kabupaten Majalengka.

Hal ini sejalan dengan penelitian yang telah dilakukan oleh Ayu Astari (2015) yang secara simultan jumlah anggota, jumlah simpanan dan pinjaman anggota berpengaruh secara signifikan terhadap SHU. Juga penelitian dari Taman (2012) yang menunjukkan bahwa Jumlah anggota, jumlah simpanan, jumlah pinjaman dan jumlah modal kerja secara simultan berpengaruh signifikan terhadap Sisa Hasil Usaha (SHU) koperasi simpan pinjam di Kabupaten Badung. Besarnya SHU yang mampu dihimpun koperasi ditentukan oleh besarnya jumlah anggota, apabila anggotanya banyak maka besarnya sisa hasil usaha juga akan banyak pula karena semakin banyak transaksi yang terjadi di Koperasi.

\section{KESIMPULAN}

1. Terdapat pengaruh jumlah anggota terhadap sisa hasil usaha pada koperasi KPRI Mitra SMA Negeri 1 Maja, Kabupaten Majalengka.

2. Terdapat pengaruh jumlah simpanan terhadap sisa hasil usaha pada koperasi KPRI Mitra SMA Negeri 1 Maja, Kabupaten Majalengka.

3. Terdapat pengaruh jumlah pinjaman terhadap sisa hasil usaha pada koperasi KPRI Mitra SMA Negeri 1 Maja, Kabupaten Majalengka.

4. Terdapat pengaruh modal kerja terhadap sisa hasil usaha pada koperasi KPRI Mitra SMA Negeri 1 Maja, Kabupaten Majalengka.

5. Terdapat pengaruh jumlah anggota, jumlah simpanan, jumlah pinjaman dan modal kerja terhadap sisa hasil usaha pada koperasi KPRI Mitra SMA Negeri 1 Maja, Kabupaten Majalengka.

\section{REFERENSI}

Baswir, Revrisond. 1997. Koperasi Indonesia.

Yogyakarta : BPFE - Yogyakarta.

Boedjioewono, Nugroho.2007.Pengantar Statistika Ekonomi dan Bisnis. Yogyakarta: Unit Penerbit dan Percetakan Sekolah Tinggi Ilmu Manajemen YKPN.

Efferin. 2004. Metode Penelitian Untuk Akuntansi Sebuah Pendekatan Praktis. Malang: Bayumedia Publishing.

Ikatan Akuntan Indonesia. 2013. Standar Akuntansi Keuangan: Entitas Tanpa Akuntabilitas Publik.

Heru Sutojo. 2007. Manajemen Keuangan. Jakarta: Salemba Empat.

Kartasapoetra. 2003. Tuntutan Praktikum. Jakarta: PT. Radja Grafindo.

Km. Bayu, dkk. 2014. "Pengaruh Modal, Volume dan Anggota terhadap Sisa Hasil Usaha Pada Koperasi Serba Usaha Kecamatan Buleleng”. ejournal. Vol 4. No 1 Tahun 2014.

Muljono, Djoko. 2012. Buku Pintar strategi Bisnis Koperasi Simpan Pinjam. Yogyakarta: ANDI OFFSET.

Rachmawaty, Vera. 2013. Pengaruh Modal Kerja Terhadap Sisa Hasil Usaha Pada Pusat Koperasi Polisi Daerah Jawa Barat (PUSKOPPOLDA JABAR. Skripsi. Jawa Barat: Universitas Pendidikan Indonesia.

Riyanto, Bambang. 2013. Dasar-Dasar Pembelanjaan Perusahaan. Yogyakarta: BPFE - Yogyakarta.

Ropke, Jochen. 2012. Ekonomi Koperasi: Teori dan Manajemen. Diterjemahkan oleh Sri Djatnika. Jakarta.

Sitio, Arifin dan Haloman Tamba. 2001. 
Koperasi: Teori dan Praktik. Jakarta: Erlangga.

Sumarso. 2005. Akuntansi Suatu Pengantar. Jakarta: Salemba Empat.

Taman, Ni Made. 2012. "Pengaruh Jumlah Anggota, Jumlah Simpanan, Jumlah Pinjaman, dan Jumlah Modal Kerja Terhadap Sisa Hasil Usaha (SHU) Koperasi Simpan Pinjam (KSP) Di Kabupaten Badung Provinsi Bali”. Jurnal Ekonomi. Bali: Fakultas Ekonomi Universitas Udayana (Unud).

Thamrin, M. 2013. "Pengaruh Simpanan dan Pinjaman Anggota Terhadap Sisa Hasil Usaha Koperasi Credit Union Pancuran Hidup Pekanbaru". Pekbis Jurnal. Vol. 5. No 1, Maret 2013: 64-72

Tohar, M. 2000. Permodalan dan Pengkreditan Koperasi. Kanisius, Yogyakarta. Untung, H. Budi. 2005. Hukum Koperasi dan Peran Notaris Indonesia. Yogyakarta : Andi, Ed. $\mathrm{T}$.

UU No.25 tahun 1992 Tentang

Perkoperasian

Usman Setiady. 2000. Metodologi Penelitian Sosial. Jakarta: Bumi Aksara.

Zainudin 2009. Metode Penelitian. Jakarta: Sinar Grafika. 